\title{
UMA ECONOMIA EM OUTONO: TRABALHADORES ESCRAVOS LIGADOS AO LABOR
}

(D) Rodrigo Caetano 1;2;

\section{RESUMO}

O principal objetivo é analisar as duas principais economias do Piauí, tendo como ponto de partida o final do século XVIII e se estendendo ao longo do século XIX. A partir dessa análise, pretendemos demonstrar que a necessidade do trabalhador escravo no Piauí estava intimamente ligada a um sistema produtivo assentado na exploração do seu trabalho. Ou seja, a existência do trabalhador cativo nas terras piauienses estava ligada ao trabalho, independentemente do crescimento econômico da região.

\section{PALAVRAS-chaVE}

Pecuária - agricultura - escravidão.

1 Universidade Federal do Pará (UFPA). Belém - Pará - Brasil.

2 Universidade Federal do Piauí (UFPI). Teresina - Piauí - Brasil.

* Historiador, doutorando em História Social da Amazônia na Universidade Federal do Pará (UFPA). Foi pesquisador do Instituto dos Advogados Piauiense (IAP). Atualmente é consultor da Ordem dos Advogados do Brasil, seção Piauí (OAB-PI) e pesquisador do Núcleo de Estudo e Pesquisa de História do Piauí Oitocentista (UFPI/CNPq) e do GEPEAM - Grupo de Estudo e Pesquisa da Escravidão e Abolicionismo na Amazônia (UFPA/CNPq). É membro pesquisador do grupo: Escravidão, mestiçagem, trânsito de culturas e globalização - séculos XV - XIX (UFMG/ CNPq). E-mail: roddrigocaetano.ufpi@gmail.com. A pesquisa realizada para criar o artigo foi financiada pela Coordenação de Aperfeiçoamento de Pessoal de Nível Superior- CAPES. 


\section{AN AUTUMN ECONOMY: WORKERS SLAVES LINKED TO LABOR}

\section{ABSTRACT}

The main objective of this article is to analyze the two main economies of Piauí, starting from the end of the eighteenth century and extending throughout the nineteenth century. From this analysis we intend to make the reader aware that the need of the slave laborer in Piauí was closely linked to a productive system that was based on the exploitation of the work of the captive. That is, the existence of the slave laborer in Piaui's lands was linked to work, regardless of the economic growth of the region.

\section{KEYWORDS}

Livestock - Agriculture - Slavery. 


\section{Uma economia em outono: pecuária}

$\mathrm{N}$ a gênese da pecuária piauiense, o gado, bovino e cavalar, era criado solto em áreas extensivas. O motivo pelo qual as fazendas necessitavam de áreas tão dilatadas explica-se pelo modo de ocupação e exploração: “a rusticidade do nível técnico dominante na pecuária e a rarefação das pastagens nos períodos estivais forçavam os proprietários a desejarem e necessitarem de grandes extensões fundiárias"'. É possível, no entanto, que nem todas as propriedades possuíssem áreas de grandes proporções, havendo também as menores, os sítios, geralmente situados "nos brejos e terras mais úmidas, onde uma pequena parcela da população se dedicava à agricultura"4.

Com a efetivação da ocupação do solo que formaria o Piauí, o número das fazendas de gado aumentou e, em 1697, existiam no local 129 dessas propriedades. Sobre o processo de expansão das fazendas de gado e os primeiros senhores dessas terras, o padre Miguel de Carvalho, em "Descrição do Sertão do Piauí", manuscrito elaborado entre 1694-1698, afirmou ao Frei Francisco de Lima, bispo de Pernambuco que,

De todas estas terras são senhores, Domingos Afonso e Leonor Pereira Marinho [viúva de Francisco Dias d'Âvila], que as partem de meias. Têm nelas algumas fazendas de gados seus, os mais arrendam a quem lhe quer meter gados, pagando-lhe dez réis de foro, por cada sítio e, desta sorte estão introduzidos donatários das terras, sendo só sesmeiros, para as povoarem com gados seus, em tanto que até as igrejas querem apresentar, e esta nova queriam fundada debaixo do título de sua. ${ }^{5}$

3 MOTT, Luiz. Piauí colonial: população, economia e sociedade. 2. ed. Teresina: Academia Piauiense de Letras, 2010. p. 64.

4 Ibidem, p. 66.

5 CARVAlHO, Miguel de. Descrição do sertão do Piauí. 2. ed. Teresina: Academia Piauiense de Letras, 2009. p. 22. 
Como é perceptível na narrativa do clérigo católico, as fazendas poderiam ser arrendadas. Esse sistema de contrato de cessão, feito mediante determinada remuneração, possibilitou o surgimento de novos senhores de fazendas ainda na gênese de exploração do território. Miguel de Carvalho ainda informa que na povoação Paulo Afonso o principal riacho era o Canindé e que próximo às suas margens existiam vinte fazendas, nas quais viviam 28 negros escravos, 25 homens brancos livres, uma mulher e um homem tapuia e uma mulher mestiça ${ }^{6}$. Percebe-se que nas primeiras fazendas do Piauí viviam poucas pessoas livres e poucos escravos, o que pode ser justificado pelo tipo de exploração econômica empregada, visto que a pecuária extensiva não necessitava de vasto uso de mão de obra.

Levando em consideração o processo de multiplicação das fazendas, desde o ano de 1697 até o ano de 1772, percebemos que em menos de um século surgiram 449 novas fazendas de gado. Em 1772, as fazendas somavam 578 - um aumento de $448 \%$ em relação ao ano de $1697^{7}$.

Por direito testamental, Domingos Afonso Mafrense, falecido em 1711, havia deixado todos os bens, incluindo suas fazendas de gado vacum e cavalar no Piauí, aos religiosos da Companhia de Jesus da Bahia. Com a expulsão dos jesuítas, as fazendas que outrora pertenciam ao sertanista Domingos Afonso Mafrense foram confiscadas pela coroa portuguesa, passando a ser denominadas Fazendas do Real Fisco ou Fazendas do Fisco. Em 8 de novembro de 1774, Manuel Antunes de Assunção, morador da freguesia de São José do Piauí, solicitou ao rei $\mathrm{D}$. José sua nomeação como inspetor das fazendas e residência de Nossa Senhora de Nazaré, antes administradas pelos jesuítas ${ }^{8}$.

Sob a administração de Manuel Antunes de Assunção, em 1778, foi feito arrolamento dos trabalhadores escravos pertencentes às fazendas da inspeção Nazaré. Na relação havia 101 escravos, entre

6 Ibidem, p. 27-28.

7 MOTT Luiz. Op. Cit., p. 72.

8 Arquivo Histórico Ultramarino. AHU_ACL_016, cx 12, Doc. 721. 
africanos, mestiços e crioulos. No rol dos escravos havia 31 com a denominação de angola, cinco minas e um originário do Congo. Os outros foram inventariados na condição de crioulos e mestiços ${ }^{9}$. Na divisão por gênero, escravos do sexo masculino somavam 68 , enquanto o número de trabalhadoras escravas era $33^{10}$.

Mesmo com o gado sendo criado solto, os escravos foram mão de obra importante para o processo de crescimento das boiadas, que não ocorreu por acaso, pois havia mercado para comercialização do gado.

A exportação das boiadas piauienses se fez para o Norte, Nordeste e centro da Colônia. Todavia, foi a região da grande lavoura que se firmou como a tradicional praça importadora da produção bovina do Piauí, não só pelo volume, mas também pela constância das remessas feitas durante o século XVII e XVIII. Em segundo lugar, destaca-se a região das Gerais. Com a intensificação das atividades mineradoras surgiram novas perspectivas para o comércio dos gados do Piauí. Com isso, a pecuária piauiense pôde extrapolar sua condição de fornecedora de carne aos núcleos litorâneos ${ }^{11}$.

A citação de Brandão deixa-nos cientes de que havia exportação de gado para variadas capitanias do Brasil. Além dela, outros autores reportam essa relação comercial do Piauí com outras partes do país durante o século XVIII. Silva, por exemplo, indica que

era comum sair dos distantes sertões do Piauí, Goiás e dos engenhos dos jesuítas localizados nas ribeiras do Itapecuru remessas de gado, couros, carnes secas, queijos, manteigas, açúcar e demais sortimentos

9 ASSUNÇÃO, Manuel Antunes de. Relação dos Escravos das fazendas da Inspeção de Nossa Senhora de Nazaré, de todos quantos nelas se acham também os da Residência com as suas idades pouco mais ou menos, [S.l: s.n], 1778. Manuscrito. Disponível em: <https://bit.ly/2TG6F4c>. Acesso em: 3 mar. 2010. 10 Ibidem.

11 BRANDÃO, Tanya Maria Pires. O escravo na formação social do Piauí: perspectiva histórica do século XVIII. Teresina: EDUFPI, 1999. p. 65. 
para a cidade de São Luís; sobretudo, a partir de 1760 até os anos finais do século XVIII. ${ }^{12}$

Segundo Mott, "entre 1770 e 1788 foram enviados 9.711 bois para a Bahia. Destes, quando os vaqueiros e tangedores vendiam alguns pelo caminho, seu preço importou em média, 1\$914 [réis]”13.

Em Capuame, eram vendidos os que saiam da bacia do Canindé, e inclusivamente os da fazenda que foram de Domingos Afonso Sertão. Gastavam de 30 a 40 dias para alcançar a feira. Viajavam geralmente no inverno, mas em certas regiões da Capitania, no período que vai de fevereiro a agosto. Em Capuame, o boi era vendido, então, a quatro mil e tantos réis. ${ }^{14}$

Ao estudar o processo de entrada de gado vacum na Bahia, Juliana da Silva Henrique encontrou nos primeiros "Livros de Registro de Entrada de Gado" as especificações dos locais de onde o gado saía para ser comercializado naquela região. Segundo a historiadora, os principais locais de origem de gado levado à Bahia eram "Piauí, Canindé, Itaim, Rio de Baixo, Rio Real [...]"15. Capuame, na Bahia, era um dos locais que consumia o gado do Piauí, porém, nem todos os anos eram enviadas boiadas àquela região, pois, em razão de fatores climáticos adversos, em alguns períodos ocorria a interrupção do fornecimento de animais. Isso é o que pôde ser observado em ofício de

12 SILVA, Mairton Celestino da. Um caminho para o Estado do Brasil: colonos, missionários, escravos e índios no tempo das conquistas do Estado do Maranhão e Piauí, 1600-1800. 2016. Tese (Doutorado em História), Centro de Filosofia e Ciências Humanas, Universidade Federal de Pernambuco. Recife, 2016. p. 175.

13 MOTT, Luiz. Op. Cit., p. 86.

14 NUNES, Odilon. Estudos de história do Piauí. 2. ed. Teresina: Academia Piauiense de Letras, 2014. p. 173.

15 HENRIQUE, Juliana da Silva. Os "Livros de Registro de Entrada de Gado" da Feira de Capoame (1784-1811). In: CONFERÊNCIA INTERNACIONAL DE HISTÓRIA ECONÔMICA, 4.; ENCONTRO DE PÓS-GRADUAÇÃO EM HISTÓRIA ECONÔMICA, 6., 2012, São Paulo. Anais... São Paulo: Universidade de São Paulo, 2012. p. 7. 
4 de maio do ano 1775 do governador interino da capitania do Piauí, António José de Morais Durão, ao secretário de Estado Marinha e Ultramar, Martinho de Melo e Castro.

Nesta mesma ocasião devemos participar a V. Excelência que no presente ano nem uma boiada se pode extrair daquelas fazendas [Fazendas do Real Fisco ou Fazendas do Fisco], para se dispuser na feira de Capuame da Bahia, como era de costume, conforme as ordens de sua Majestade; porque a extraordinária seca deste inverno fez impossível o transitarem aquelas pelas travessia, conforme a declaração dos inspetores feita por termo na nossa presença e constante da certidão junta constando-nos antes disso plenamente, que alguns gados de particulares, que tentaram aquela passagem experimentaram ou total ou gravíssima ruina, a qual presentemente deveríamos evitar na fazenda do dito senhor, mandando se conserva-se o gado nos próprios pastos, em que haverá menos perigo, para falir no ano futuro. ${ }^{16}$

Pelo teor do documento, podemos coligir que era costume levar gado vivo do Piauí para ser vendido na feira de Capuame. Contudo, muita carne de gado vacum foi vendida de forma processada. Os locais de processamento da carne eram as charqueadas.

Até início do século XIX, foi forte o estabelecimento das charqueadas em Parnaíba, tendo sido um dos primeiros a estabelecer a indústria de charque o português Domingos Dias da Silva, que "teria chegado ao Piauí em 1758, procedente do Rio Grande do Sul, estabelecendo-se à margem esquerda do rio Igaraçu, chegando a implantar seis unidades produtivas"17. As charqueadas foram de suma importância para o desenvolvimento econômico do Piauí e, a exemplo de outros polos produtores de charque no Brasil, as charqueadas parnaibanas concentravam um grande número de trabalhadores escravos ${ }^{18}$.

16 Arquivo Histórico Ultramarino. AHU_ACL_CU_16, cx. 12, Doc. 730.

17 LIMA, Solimar Oliveira. Trabalho escravo nas charqueadas do Piauí: uma aproximação. Informe econômico. Teresina, publicação do Departamento de Ciências Econômicas-UFPI, n. 15, jun. 2003, p. 10.

18 Ibidem, p. 10. 
Diderot Mavignier aponta que "nos registros do início da década de oitenta do século XVIII, consta que nas charqueadas de Parnaíba, era abatida, anualmente uma média de quarenta mil bois, exportados juntamente com uma média de trinta mil couros com cabelos e quatro mil peças de sola"19. O comércio de charque em Parnaíba era tão representativo que, em 13 de fevereiro de 1786, o governador do Maranhão e Piauí, José Teles da Silva, informou por ofício o Conselho Ultramarino sobre o grande comércio de carnes e peles praticado na vila de São João da Parnaíba e sua extensão a Lisboa. Devido a isso, propôs a criação de uma Alfândega no porto daquela vila ${ }^{20}$.

No século XVIII, o gado piauiense abastecia não somente a Bahia, mas também Pernambuco, Maranhão, Pará, Rio Grande do Norte, Paraíba e Minas Gerais, de modo que o volume comercializado pela pecuária piauiense atingiu valores expressivos. Por exemplo, na segunda década do século XVIII, somente a cidade de Belém, no Pará, comprava anualmente do Piauí entre 28 mil e 30 mil cabeças de gado ${ }^{21}$.

Além do comércio lícito, havia também a comercialização ilegal do gado piauiense. Em virtude disso, em 1 de junho de 1731, foi feita consulta sobre a correspondência do ouvidor-geral da capitania do Piauí, Antônio Marques Cardoso, acerca do roubo e transporte de gado dos sertões do Piauí para Pernambuco, Bahia e Minas Gerais.

19 MAVIGNIER, Diderot dos Santos. No Piauhy: na terra dos Tremembés. Parnaíba: Sieart, 2005. p. 57.

20 Ibidem, p. 59.

21 Cf. BRANDÃO, Tânia Maria Pires. A elite colonial piauiense: família e poder. 300 f. Tese (Doutorado em História Social) - Faculdade de Filosofia, Letras e Ciências Humanas, Universidade de São Paulo, São Paulo, 1993. 
[...] Ordenando-se por Provizão deste Conselho de no-/ve de Septembro de mil SeteCentos e vinte e Seis/ao Ouvidor geral da Villa da Moxa, ouvisse as/Cammeras desta Villa do Piauhy Sobre os/grandes Latrocinios que fazem os que Levão gados/ dos Certões das ditas villas para as povoações de/Pernambuco, Bahia e Minas introduzindo/nelles gados alheios, e que as ditas Cammeras des-/sem pôr escripto as razões que Se lhes oferessessem/para Se evitarem estes furtos [...]. ${ }^{22}$

A venda de gado vivo e de seus derivados constituiu-se por muito tempo na principal atividade econômica do Piauí, possibilitando aos cofres públicos um considerável aporte de recursos: "o maior rendimento da província procedia do imposto de 10 por cento sobre o gado"23. Assim, podemos dizer que, economicamente, o gado vacum foi "o açúcar e o café" do Piauí.

Porém, no final do século XVIII, a economia pecuarista entrou em processo de decadência, em razão da queda nos níveis de rendimento, o que, contudo, não foi suficiente para sua extinção. A segunda metade do século XVIII foi marcada por mudanças econômicas em outras regiões, criando condições desfavoráveis à economia pecuarista piauiense, que, assim, entrou em um período outonal. Verifica-se, por exemplo, que a economia de algumas regiões passava por diversificação, com desenvolvimento de atividades como a pecuária e a agricultura. Com efeito, o desenvolvimento da atividade pecuarista em algumas áreas do Brasil foi fator determinante para a retração econômica da pecuária piauiense, que não estava preparada para a concorrência por mercados, no final do século XVIII. Com isso, mercados consumidores de gado e carne já processada passaram a ser providos por fornecedores mais próximos.

22 Arquivo Histórico Ultramarino. AHU_ACL_CU_16, Cx. 1, Doc. 68.

23 MOTA, Ignácio Francisco Silveira da. Relatório do presidente da província do Piauí. [S.l.: s.n.], 1850. p. 24. 
Nesse processo outonal ${ }^{24}$ da economia pecuarista piauiense, devemos levar em consideração a questão logística. O gado criado no Piauí normalmente era conduzido por longas distâncias até os locais das feiras, em viagens que duravam vários dias. Isso prejudicava a qualidade da carne: um gado submetido a longas jornadas tinha carne mais dura, o que não era um problema até haver uma pecuária mais competitiva em outras regiões do país. Assim, com o desenvolvimento da pecuária em outras áreas, mais próximas de mercados consumidores, regiões que outrora compravam o gado piauiense passaram a adquirir animais de produtores mais próximos, obedecendo a razões de ganho econômico e logístico.

Ainda no século XVIII, as charqueadas parnaibanas passaram a enfrentar concorrência de atividade similar no Sul do Brasil. Mavignier aponta que, "com a instalação de charqueadas no Sul do Brasil, entraram em declínio as indústrias de carne seca do Nordeste e, em 1827, deixou de funcionar a última charqueada de Simplício Dias em Parnaíba"25.

Embora em outras regiões avançassem novas formas de manejo do gado, no início do século XIX a criação extensiva no Piauí se mantém como se praticava na gênese da ocupação do território. O modo de criação de bovinos foi o mesmo durante os séculos XVIII e XIX:

Ainda feita como nos tempos primitivos de Mafrense, em fins do século XVII. Esta indústria que tão grandes vantagens poderiam deixar, se melhores fossem as suas condições e a viação pública para os mercados em que o gado é vendido, não deixa o resultado que era de esperar e

24 Optamos pelo conceito de outono e não de fim, declínio ou ocaso, porque pareceu mais apropriado. Ora, sendo o outono a estação do ano caracterizada pela perda de folhagens das árvores, que assim entram em um processo de latência, de modo que haja reservas de energia para a renovação da folhagem que acontece na primavera, podemos estabelecer um nexo com a economia pecuarista do Piauí.

25 MAVIGNIER, Diderot dos Santos. Op. Cit., p. 107. 
não oferece seguras garantias ao criador; o gado de exportação é levado a pé a longínquas paragens nas províncias do Ceará, Rio Grande do Norte, Paraíba, e Pernambuco, com grande prejuízo e dificuldades. ${ }^{26}$

A manutenção do modo tradicional de criação do gado também pode ser apontada como uma das causas da retração econômica da pecuária piauiense, na medida em que o modelo adotado pelos fazendeiros se baseava em uma atividade criatória de exploração extensiva. Desse modo, permanecendo a prática rudimentar de criar gado e, diante do desenvolvimento da pecuária em outras áreas, houve uma diminuição no número de gado bovino vendido para fora da província piauiense, provocando um momento de outono na economia pecuarista.

No século XVIII, a possibilidade de maior arrecadação de impostos com o crescimento da venda de animais levou as autoridades sul-rio-grandenses a se preocuparem com a melhoria nas condições de deslocamento do gado. Assim, foram feitas estradas para facilitar o transporte do gado para os locais de venda ${ }^{27}$.

Na primeira metade do século XVIII foi concluída a primeira estrada entre as províncias do Rio Grande do Sul e de São Paulo, favorecendo a economia pecuarista sul-rio-grandense. Para Nunes, até a abertura da estrada que ligava a região de São Paulo à das Minas Gerais e do Rio Grande do Sul (1727-1734), a economia pecuarista sul-rio-grandense pouco afetou a da região Nordeste ${ }^{28}$. A abertura de estradas que facilitavam o transporte do gado começou a mudar o eixo da criação de gado no Brasil, deslocando-o do Nordeste para o Centro-Sul do país:

26 COSTA, apud COSTA FILHO, Alcebíades. A escola do sertão: ensino e sociedade no Piauí, 1850-1889.

Teresina: Fundação Cultural Monsenhor Chaves, 2006. p. 24.

27 Cf. MORAES, Carlos Dante. Figuras e ciclos da história rio-grandense. Porto Alegre: Globo, 1959. 28 NUNES, Odilon. Estudos de história do Piauí... Op. Cit., p. 162-163. 
A partir de então, com a abertura da estrada que ligava o Rio Grande do Sul à zona mineira, os bois do sertão passaram a enfrentar concorrência do gado dos pampas. Os efeitos podem ser verificados nas arrecadações de dízimos. Em 1730, correspondeu a 76.000 cruzados, enquanto que 24 anos depois foram estes arrematados por $66.750 \mathrm{cru}-$ zados, ou seja, 26:700r\$000. ${ }^{29}$

O Sudeste do Brasil, outrora abastecido pelo gado do Piauí e por outras províncias do Nordeste, a exemplo da Bahia, passou também a receber o gado criado nos Pampas gaúchos. Segundo Nunes, em 1725, foi fundado o entreposto do sul do canal do Rio Grande do Sul e, assim, começou o processo de tirada de gado não somente das vacarias - denominação que os jesuítas espanhóis atribuíram aos locais onde iniciou a criação de gado, como também das áreas que abasteceriam os aldeamentos indígenas organizados e administrados pelos padres jesuítas ${ }^{30}$.

Dessa forma, a pecuária do Sul do Brasil entrava em franca competição com a do Nordeste, que tinha, então, "suas melhores e mais numerosas manadas no Piauí, e dentro de pouco tempo a exportação do Sul passaria a ocupar posição superior à do resto do Brasil, ou melhor, de todas as colônias portuguesas na América"31.

Há que se considerar, no entanto, que o avanço da pecuária no Rio Grande do Sul se dá em condições de clima e solo bastante distintas daquelas existentes no Piauí, com solo mais arenoso, menor índice de chuva e pastagens naturais diferentes das observadas nos pampas. Assim, é possível afirmar que "a diferença, sob esse aspecto, consistia obviamente em maior número de vantagens para a região Sul”32. Além dessas vantagens geográficas, a região Sul possuía outros fatores que lhe favoreciam: "seu gado ficava bem próximo do litoral, com ricas pastagens saturadas de sal pelas virações marítimas.

\footnotetext{
29 BRANDÃO, Tanya Maria Pires. O escravo na formação social do Piauí ... Op. Cit., p. 65. 30 NUNES, Odilon. Estudos de história do Piauí... Op. Cit., p. 166.

31 Ibidem, p. 170.

32 Ibidem, Loc. Cit.
} 
Era de capital importância o suprimento de sal na própria pastagem em vez de na argila, em lambedouros naturais, às vezes, com grande percentagem de sílica"33.

As condições físicas do sertão contribuíram para que o gado apresentasse baixa estatura e pouca carne. Assim, as condições de criação e do clima que se apresentavam no sertão, cujo solo era coberto por pastos secos e extensas áreas sujeitas às secas prolongadas, conformaram o gado vacum a animais ossudos ${ }^{34}$. Já o gado cavalar se dava bem no sertão, mas tinha uma multiplicação inferior ao vacum, devido à falta de forragem apropriada. Talvez isto, mais que a falta de cruzamento, explique a baixa estatura. Contudo, sua resistência ao trabalho era incomparável, pois a exiguidade do porte físico apropriava-o às corridas pela caatinga ${ }^{35}$.

Desse modo, é aceitável admitir que o gado, vacum e cavalar, do Piauí também passasse por um processo de adaptação ao meio climático em que estava inserido, tendo em vista que o Piauí possuía parte do seu solo coberto por pastos secos e estava sujeito a secas prolongadas. Neste sentido, "em decorrência das transformações físicas pelas quais passaram os rebanhos é que a preferência dos compradores se voltou para os rebanhos do Sul do Brasil, provocando assim a baixa do preço no mercado"36. Quanto ao rebanho cavalar, "cuja importância era menor como produto de mercado do que como peça fundamental na atividade do vaqueiro, o processo de adaptação ao meio piauiense foi favorável às atividades sertanejas"37.

No que diz respeito à pecuária piauiense, Brandão ressalta:

33 Ibidem, p. 170-171.

34 RIBEIRO, Darcy. O povo brasileiro: a formação e o sentido do Brasil. 2. ed. São Paulo: Companhia das Letras, 1995. p. 344.

35 ABREU, Capistrano de. Capítulos de história colonial: 1500-1800. Brasília: Conselho Editorial do

Senado Federal, 1998. p. 203.

36 COSTA FILHO, Alcebíades. Op. Cit., p. 25.

37 Idem. A escola do sertão... Op. Cit., p. 25. 
Nas três últimas décadas do século XVIII, observa-se tendência de baixa no preço do gado, podendo esta ser atribuída à excessiva produção em relação à capacidade de absorção dos mercados. Se, por um lado, continuou sendo a região litorânea a mais importante dos mercados; por outro, além da concorrência firmada pela pecuária do Sul, as demais capitanias contavam nessa ocasião com rebanhos locais. Isso sem falar nas dificuldades que porventura surgiam em decorrência da crise econômica colonial e que certamente limitava o poder aquisitivo da população. ${ }^{38}$

Ao fim do século XVIII, em Minas Gerais, o esfacelamento das jazidas de ouro foi seguido pela diversificação econômica da região, tendo como bases principais as atividades do setor agrícola e na pecuária. "A importação de alimentos básicos foi cedendo à produção interna, tanto mais que a alta de preço provocada pela extração do ouro tornava a agricultura uma atividade lucrativa. A pecuária se desenvolveu a ponto de, já em 1765, descer gado de Minas Gerais para o mercado do Rio de Janeiro" 39.

Para Gorender, "além da divisão dos pastos e de práticas de separação do gado, os fazendeiros mineiros industrializavam o leite, dele extraindo o queijo - produto comercial de ampla circulação no mercado interno"40. Dessa forma, percebe-se que no final do século XVIII a atividade pecuarista mineira passou por processo de aprimoramento. No século XIX, Minas Gerais possuía “a pecuária mais evoluída do país do ponto de vista técnico e a mais escravista e mercantilizada"41. Nesse sentido, a região Centro-Sul do Brasil, outrora abastecida com gado piauiense, passou a ser provida pelo gado do Rio Grande do Sul e das Minas Gerais. Com o desenvolvimento da atividade pecuarista daquelas regiões, que ocasionou a autossuficiência no abastecimento de seu mercado e possibilitou exportar gado para os mercados de ou-

38 BRANDÃO. O escravo na formação social do Piauí... Op. Cit., p. 69.

39 GORENDER, Jacob. O escravismo Colonial. 4. ed. São Paulo: Fundação Perseu Abramo, 2010. p. 487. 40 Ibidem, p. 458.

41 GORENDER, Jacob. O escravismo Colonial... Op. Cit., p. 487. 
tras áreas, a exportação do gado piauiense sofreu redução, visto que houve diversificação da economia e desenvolvimento da atividade pecuarista nas áreas que antes compravam gado do Piauí.

Em documento de título "Proclamação", a Junta do Governo Temporário escrevia aos habitantes do Piauí as seguintes palavras:

Habitantes da Província do Piauí esta Capital do dia vinte e quatro de corrente proclamou a Independência do Brasil e reconheceu o governo do Imperador Constitucional, e perpétuo defensor deste Reino o senhor Dom Pedro I e as Cortes Brasileiras. Este é o passo que tem dado quase todas as Províncias do vasto continente Brasileiro o que vós não podeis escusarmos. E como a Província do Maranhão não adota por agora o sistema da Independência, nem ao certo se pode saber se fica ou não neutral a respeito desta segundo o procedimento que teve com a Vila da Parnaíba quando em dezenove de outubro do ano passado se antecipou a declarar a sair aderência: este Governo já se dirigiu às duas primeiras autoridades daquela Província exigindo e vogando a dita neutralidade, porém como pode ser que se neguem a tão justa requisição, tem este mesmo Governo resolvido e ordenado que, no entanto, se recebe resposta do Governo do Maranhão não saia para ali gado vacum de qualidade alguma, pois não é justo que sustentemos aqueles mesmos que ajudam e concorrem para se derramar o nosso sangue e sofremos outros mil incômodos de que, aliás, ficaríamos livres se o Maranhão se conservasse neutral. Todavia, a dita proibição se limita só unicamente ao gado, pois que, todo o mais comércio e comunicação é livre com aquela província. E mesmo a proibição do gado se cessará logo que o Governo do Maranhão declarar que nos não incomodar a opor nosso sistema político. Portanto, habitantes do Piauí não se porteis por hora para o Maranhão os vossos gados, não leveis o alimento para donde vos não sabeis se vos virá o mal e a opressão. E alguém de vos que assim o fizer então é por que não ama a sua pátria e com horror deve ser olhado pelos seus patrícios. Este Governo a todos vos recomenda a religiosa observância do quando se vos determina e assim o espera do vosso patriotismo. Palácio do Governo em Oeiras aos trinta de janeiro de 1823. Manoel de Souza Martins, Presidente: Manoel Pinheiro de Miranda Ozorio, Secretario: Ignacio Francisco de 
Araújo Costa: Miguel Jose Ferreira: Honorato José de Morais Rego.42

Nessa citação há informações importantes para situarmos o leitor de que o Piauí no século XIX, mesmo passando por fase outonal na economia pecuarista, continuava exportando gado bovino, e mais, ela serve para verificar a importância do gado vacum piauiense, visto que ele estava sendo utilizado pelo presidente da capitania do Piauí, Manoel de Souza Martins, como objeto de barganha para a independência do Brasil.

É importante esclarecer que, apesar da economia pecuarista sofrer perdas de mercado, o gado continuava sendo criado e o número de fazendas continuava crescendo. Se em 1697 existiam no Piauí 129 fazendas de gado, em 1858 esse número aumentou consideravelmente. Analisando o quadro demonstrativo do número de fazendas de criação de gado vacum e cavalar de 1858, podemos perceber que o número de fazendas existentes no Piauí era de $5.013^{43}$, ou seja, teve um aumento de 4.884 fazendas em um período de 161 anos.

No relatório do presidente da província, Franklin Américo de Menezes Doria, há informações sobre a venda de gado e outros gêneros que fora realizada no ano de 1864 . Os dados são referentes ao início do ano de 1864, período que corresponde aos meses de fevereiro e maio. Nesse intervalo foram exportadas aproximadamente 3.219 toneladas de produtos para outros portos, dos quais 1.287 toneladas eram de gado. As informações se referem a um momento preciso da segunda metade do século XIX, mas podemos observar que o gado ainda era um produto de grande importância, pois quase metade dos produtos exportados era formada por gado. Percebe-se também que o gado piauiense era comercializado dentro e fora do império. Pelos

42 PIAUÍ. Fazendas Nacionais. Livro de registro dos oficios e mais ordens expedidas pelo Governo Temporário: Vai rubricado por mim e depois de numerado, como presidente do mesmo Governo. Oeiras: [s.n.], 25 de janeiro de 1823. Caixa: 147.

43 JUNQUEIRA, João José de Oliveira. Relatório do presidente da província do Piauí. [S.l.: s.n.], 1858. Mapa Letra C. 
dados do relatório, a comercialização interna do gado era feita com a província do Maranhão, já a externa feita com Caiena, na Guiana Francesa. O gado era levado para o porto da Guiana Francesa por embarcações brasileiras pertencentes à província do Maranhão e por embarcações norte-americanas das cidades de Salem e Newport, nos Estados Unidos ${ }^{44}$; ou seja, os fazendeiros piauienses continuavam comercializando gado no mercado interno da província piauiense, vendendo reses para outras áreas do Brasil, a exemplo de Pernambuco, Bahia, Ceará, Maranhão e Pará45, e exportando para fora do império, a exemplo da Guiana Francesa.

Mas, no século XIX, a quantidade de gado vendida não era a mesma de outrora, devido principalmente à conjuntura externa às terras piauienses, de modo que havia necessidade de implementar a economia. Muitos fazendeiros buscaram alternativas para manter a lucratividade e os vínculos com setores e regiões mais dinâmicas. Dessa forma, "no início dos oitocentos, aumentou a diversificação produtiva [no Piauí], no sentido de deslocar acumulação para explorar também outras atividades lucrativas, como a agricultura mercantil"46.

\section{Uma economia em transformação: agricultura}

No Piauí, paralela à pecuária, havia a atividade agrícola. No entanto, é necessário precisar os momentos da agricultura nessas plagas, pois há períodos em que ela é voltada principalmente para a subsistência da população ou para o abastecimento do mercado interno

44 DORIA, Franklin Américo de Menezes. Relatório do presidente da província do Piauí. [S.l.: s.n.], 1864. Anexo: n. 8 B.

45 JUNQUEIRA, João José de Oliveira. Op. Cit., p. 10-11.

46 LIMA, Solimar Oliveira. Origens e espaços de produção das fazendas pastoris do Piauí. In:

MAESTRI, Mário (Org.). Peões, vaqueiros e cativos campeiros: estudo sobre a economia pastoril no Brasil. Passo Fundo: UPF Editora, 2009, p. 349-375. p. 373. 
e o momento em que assume característica de atividade produtora mercantil. Podemos dizer que no início do século XIX houve entre a pecuária e a agricultura piauienses o início de um processo de inversão do crescimento econômico, porém é importante pontuar que até as primeiras décadas do século XX a pecuária continuava sendo o principal produto econômico do Piauí. Mas, no decorrer dos anos oitocentos e principalmente durante os séculos que se seguiram, a inversão econômica entre pecuária e agricultura tornou-se ainda mais perceptível ${ }^{47}$.

A economia pecuarista, em sua gênese, foi desenvolvida não apenas para abastecer o mercado interno do Piauí, mas principalmente o externo; já a agricultura em seu momento embrionário foi desenvolvida para abastecer tão-somente a população local, ou seja, o mercado interno.

O trabalho nos roçados era desenvolvido de acordo com o calendário de plantio. Esse tempo estacional permitia a liberação temporária de mão de obra do pastoreio, principalmente no período de pre-

47 Essa inversão econômica de crescimento ocorreu durante o início do século XIX e perdura até os dias contemporâneos. A produção agrícola do Piauí (cereais, leguminosas e oleaginosas) do ano de 2016 registrou safra de 1.415.424 toneladas. Em 2015, a safra foi de 3.056.112 toneladas. Segundo a Fundação Cepro, a baixa na safra do ano de 2016 foi devido à má distribuição das chuvas durante o período do plantio e do ciclo das culturas, que provocou resultados negativos na produção de grãos do estado. Contudo, se no ano de 2016 a safra do Piauí foi baixa em relação às safras de outros estados, no ano seguinte, 2017, ela foi recorde. A projeção da safra anunciada pelo IBGE para o ano de 2017 foi a maior da história do estado do Piauí, e mais de $180 \%$ maior que a colheita do ano de 2015. Segundo o levantamento feito nos 224 municípios piauienses, a safra foi de cerca de 4.078.693 toneladas, puxada pela soja, com produção esperada de 2.207 .204 toneladas. O milho segue como a segunda mais importante cultura no estado, com 1.637 .670 toneladas. Por outro lado, a economia pecuarista, não só no Piauí, mas em toda a região do Matopiba, área que compreende os estados do Maranhão, Tocantins, Piauí e Bahia, tem-se mostrado tímida em relação à produção de soja, milho e arroz, principalmente. Cf. BUAINAIN, Antônio Márcio; GARCIA, Junior Ruiz; VIEIRA FILHO, José Eustáquio Ribeiro. Dinâmica da economia e da agropecuária no Matopiba. Rio de Janeiro: Ipea, 2017; INSTITUTO BRASILEIRO DE GEOGRAFIA E ESTATÍSTICA. Levantamento sistemático da produção agrícola. Rio de Janeiro: IBGE, 2017. Disponível em: <https:// bit.ly/38lupA5>. Acesso em: 4 abr. 2020; FUNDAÇÃO CENTRO DE PESQUISAS ECONÔMICAS E SOCIAIS DO PIAUÍ. Conjuntura econômica e social: boletim analítico anual, 2016. Teresina: Cepro, 2017. Disponível em: <https://bit.ly/3aniixu>. Acesso em: 4 mar. 2020. 
paração da terra para o cultivo. Nesse sentido, o trabalho nos roçados era ocasional e acessório à produção pastoril ${ }^{48}$.

Essa característica de pequena agricultura perdurou na economia piauiense até o final do século XVIII, mas no começo do século seguinte teve início um processo de inversão de crescimento econômico entre pecuária e agricultura.

Na primeira metade do século XIX, iniciou-se a fase de transição da agricultura de subsistência para a mercantil, com a manutenção de áreas de cultivo - fazendas e sítios - como locais de plantio. Esses espaços eram os mesmos estabelecidos na pequena agricultura praticada no século XVIII: na fazenda, a agricultura se voltava exclusivamente para o consumo interno; já a produção no sítio possuía contato fortuito com o mercado, limitando-se a pequenas feiras existentes em vilas durante a safra ${ }^{49}$. O que muda, então, no início do século XIX? "Forjava-se um processo em que a produção primeiramente visava ao mercado; não se tratava, portanto, de comercialização de excedente. A lógica, ao que parece, era suprir a demanda externa, negligenciando o consumo interno, especialmente o dos trabalhadores"50.

Nesse sentido, houve retração no mercado de consumo interno de produtos agrícolas. Com isso, a base alimentar da população, especialmente dos trabalhadores, tendeu à concentração em torno da carne bovina. Desse modo, houve diversificação na dieta alimentar da população piauiense, o que significou aumento do número de reses abatidas para o consumo interno.

Devido ao recuo econômico que a pecuária sofreu, alguns fazendeiros piauienses tiveram que se adequar à nova realidade econômica. A solução encontrada foi a diversificação da economia para manter os proprietários e um padrão de acumulação, tendo como

48 LIMA, Solimar Oliveira. Fazenda: pecuária, agricultura e trabalho no Piauí escravista (séc. XVII-XIX). Teresina: EDUFPI, 2016. p. 95.

49 Ibidem, p. 96.

50 Ibidem, p. 97-98. 
base a pecuária e a agricultura ${ }^{51}$. Mesmo com essa dinamização na agricultura, ela não foi capaz de manter os ritmos econômicos da pecuária, atividade que, apesar do momento de outono, permaneceu como a principal economia arrecadadora de dízimo para a província piauiense.

Em síntese, no século XIX, a economia pecuarista não tinha os mesmos padrões de sua fase embrionária e a agricultura, inicialmente voltada sobretudo para a subsistência da população piauiense, passou a ser uma economia mercantil, dirigida ao mercado externo às terras piauienses e às terras do Brasil.

Nas caixas de coletoria, deparamo-nos com documento do ano de 1876 do munícipio de Parnaíba com uma série de informações sobre as atividades agrícolas e pecuaristas realizadas na localidade. De acordo com o registro, em Parnaíba, no ano de 1876, eram cultivados os seguintes produtos: algodão, arroz, cana, feijão, fumo, mandioca e milho ${ }^{52}$. O documento também indica que o serviço de transporte era realizado em carros de boi e que havia doze carros e 48 animais eram utilizados. Em 1876, foram produzidos no município de Parnaíba: 795.151 quilos de algodão, 1.300 litros de arroz, 50.250 litros de farinha de mandioca, 6 mil litros de feijão, 2.655 quilos de fumo em rolo e 10.104 litros de grão de milho. Além disso, pelas informações do documento, com a cana não se fazia açúcar e sim aguardente, cuja produção em 1876 em Parnaíba foi de 8 mil litros ${ }^{53}$.

O documento também indica que em 1876 havia em Parnaíba 150 fazendas exclusivas de criação. A quantidade de animais era a seguinte: 9.600 cabeças de gado bovino, 550 de gado cavalar, cinquenta de gado muar, mil de gado lanígero ${ }^{54}$, oitocentas de gados cabrum e

51 Ibidem, p. 12.

52 PIAUÍ; Secretaria de Governo; Fundo- Palácio do Governo; Grupo- Parnaíba; Série- Alfândega de Parnaíba; Ano- 1835-1928.

53 PIAUÍ. Alfândega de Parnaíba... Op. Cit. Ano- 1835-1928.

$54 \mathrm{O}$ mesmo que carneiro ou ovelha. O nome diz respeito a animais que produzem lã ou são providos de lã. 
duas mil de gado suíno. Nesse momento a indústria do charque em Parnaíba já não existia e a pecuarista estava produzindo apenas: sebo (quinhentos quilos), couro seco (aproximadamente 14 mil quilos) e couro salgado (aproximadamente 15 mil quilos) ${ }^{55}$. Havia exportação de alguns gêneros, como algodão e fumo, que eram vendidos para as províncias do Maranhão e do Ceará e para Liverpool ${ }^{56}$. Um dos produtos mais exportados da província piauiense era o algodão, sujeito, porém às enfermidades que ano a ano o perseguem ${ }^{57}$.

Na segunda metade do século XIX, ocorreu o aumento da exportação do algodão piauiense para fora do Brasil, o que possibilitou aumentar os lucros na agricultura da província, pois o Piauí exportava algodão para a Europa. No relatório do presidente da província do Piauí - Adelino Antônio de Luna Freitas - podemos verificar que entre os anos de 1857 e 1865 foram exportadas: 169.739 arrobas de algodão, seguidas por 147.42 arrobas tatajuba ${ }^{58}, 17.836$ de fumo e 11.98 de sebo ${ }^{59}$.

Contudo, se, por um lado, o Piauí exportava algodão para fora do império, por outro, importavam-se produtos para a alimentação da população, como açúcar, arroz e café, do Ceará, Maranhão e Pernambuco. Essa prática era realizada porque a produção desses produtos no Piauí era pequena, como afirma o presidente, Antônio Francisco Pereira de Carvalho: "além da cultura do algodão e fumo, existia a da cana, a do arroz, milho, feijão e mandioca; porém esses últimos artigos não são produzidos em grande quantidade que possam ser

55 PIAUÍ. Alfândega de Parnaíba... Op. Cit. Ano- 1835-1928.

56 Idem. Alfândega de Parnaíba... Op. Cit. Loc. Cit.

57 CARVALHO, Antônio Francisco Pereira de. Relatório do presidente da província do Piauí. [S.l.: s.n.], 1854. p. 17.

58 Tatajuba é o nome popular de uma árvore da família das moráceas, de grande porte, com até trinta metros de altura. É nativa da região amazônica e encontrada no Suriname e na Guiana. Sua madeira tem alta resistência e é usada na construção civil, marcenaria, construção naval e laminados. Também é chamada de amaparana, bagaceira, cachaceiro, pente-de-macaco, amarelão.

59 FREIRE, Adelino Antônio de Luna. Relatório do presidente da província do Piauí. [S.l.: s.n.], 1867. 
exportados, mas somente são suficientes para o consumo da província"60.

Acrescenta-se que em 1876, dentre os indivíduos empregados nas atividades realizadas no munícipio de Parnaíba, 64 eram pessoas livres, 120 estavam na condição de escravos ${ }^{61}$. Além disso, fica patente a predominância da mão de obra escrava em relação à livre nas atividades realizadas no local.

Na caixa de coletoria do município de Valença, encontramos um documento com sentido semelhante ao anterior. Percebe-se que em Valença, em 1875, data do documento, havia cultura dos seguintes produtos: algodão, arroz, batata, cana, feijão, fumo, mandioca e mi$\mathrm{lho}^{62}$. É possível observar que não havia máquinas modernas para clarear o açúcar e moer cereais. Empregavam-se animais para o transporte e 580 estavam encarregados de realizar esse serviço ${ }^{63}$.

Em 1875 foram produzidos em Valença 1.500 quilos de algodão, 1.260 litros de arroz, 150 quilos de batata, 1.500 quilos de açúcar, 60 mil litros de aguardente, 960 mil litros de farinha de mandioca, 320 mil litros de feijão, 1.500 quilos de fumo em rolo e 680 mil litros de grão de milho ${ }^{64}$.

Existiam no município de Valença, em 1875, 48 fazendas exclusivas para criar animais, com as seguintes quantidades: 8 mil cabeças de gado bovino, 694 cabeças de gado cavalar, 80 cabeças de gado muar, 1.500 cabeças de lanígeros e 1.200 cabeças de cabruns. Nesse munícipio a indústria pecuarista praticamente não existia, produzindo apenas couro seco, 2.600 quilos no ano do documento ${ }^{65}$.

Dos indivíduos empregados nas atividades no munícipio de Valença, 120 eram livres e quarenta eram escravos. Diferentemente de

60 CARVALHO, Antônio Francisco Pereira de. Op. Cit., p. 17.

61 PIAUÍ. Op. Cit., Ano- 1835-1928.

62 PIAUÍ. Secretária de Governo do Piauí. Assunto: munícipio- Valença. Anos: 1875 a 1893.

63 PIAUÍ. Munícipio- Valença. Loc. Cit.

64 PIAUÍ. Munícipio- Valença. Loc. Cit.

65 PIAUÍ. Munícipio- Valença. Loc. Cit. 
Parnaíba, em Valença havia predominância de trabalhadores livres. Os produtos exportados desse munícipio eram açúcar, rapadura, aguardente, farinha, milho, feijão e batatas, havendo maior diversificação que em Parnaíba. Os destinatário eram os munícipios de Oeiras, Amarante e Teresina e também a província do Ceará ${ }^{66}$.

Na caixa de coletoria do munícipio de São Raimundo Nonato encontramos documento com conteúdo semelhante aos documentos sobre Parnaíba e Valença. Nesse munícipio, em 1875, data do documento, havia plantações de cana, algodão, arroz, batata, feijão, fumo, mandioca e milho. Também existiam quinze engenhos para transformar a cana-de-açúcar em melado, todos movidos por animais (120 vacuns). Acrescente-se que, segundo as informações do documento, não havia máquinas modernas para clarificação do açúcar. Mais ainda, havia 110 fazendas exclusivas de criação de animais e a indústria pecuarista de São Raimundo Nonato produzia charque, sebo, couro seco, couro salgado e cabelos. Dos indivíduos empregados nos serviços daquele município, 250 eram livres e 150 eram escravos. Assim como em Valença, havia uma predominância de pessoas livres trabalhando no município de São Raimundo Nonato ${ }^{67}$.

Apontamos informações relativas à produção de gêneros agrícolas praticada em três munícipios piauienses durante a segunda metade do século XIX, confirmando que os documentos ratificam nossa argumentação: a agricultura piauiense não era desenvolvida apenas para abastecer o mercado interno, havia exportação de produtos agrícolas para outras áreas do Brasil e para outras nações. Além disso, concluímos que havia um forte intercâmbio comercial entre o Piauí e outras províncias do Brasil e outras nações, fortalecido por negociações comerciais. Destaca-se que na década de setenta do século XIX o trabalho realizado nos municípios citados era assentado

66 PIAUÍ. Munícipio- Valença. Loc. Cit.

67 PIAUÍ. Secretária de Governo do Piauí. Assunto: munícipio- São Raimundo Nonato. Ano: 1875. 
predominantemente na mão de obra livre, ou seja, nesse período é possível observar uma transição da mão de obra escrava para a livre.

\section{O crescimento da população escrava no Piauí}

O crescimento da população escrava pode ser percebido nos relatórios dos presidentes da província. A Tabela 1 sintetiza a análise dos relatórios dos presidentes e do censo de 1872 .

\section{Tabela 1 - Número de escravos}

\begin{tabular}{|c|c|}
\hline Ano & Número de escravos entre homens e mulheres \\
\hline 1762 & 4.644 \\
\hline 1798 & 13.250 \\
\hline 1830 & 12.534 \\
\hline 1865 & 19.204 \\
\hline 1871 & 19.015 \\
\hline 1872 & 23.795 \\
\hline
\end{tabular}

Fonte: Freitas, 1868; Souza Leão, 1871; Brasil, 1872.

No ano de 1762, quando a capitania do Piauí era governada por João Pereiras Caldas, o número de escravos era de 4.644. Essa população estava dividida entre os seguintes municípios: São João da Parnaíba (613); Campo Maior (619); Marvão, hoje Castelo do Piauí (288); Valença (613); Oeiras (1.549); Jerumenha (326); Parnaguá (636) ${ }^{68}$.

Passados 36 anos desde 1762, a população de cativos aumentou consideravelmente no Piauí, havendo em 179813.250 escravos, ou seja, 8.606 novos cativos. Os escravos estavam distribuídos nos seguintes municípios: São João da Parnaíba (2.541); Campo Maior (1.992); Va- 
lença (1.166); Oeiras (3.893); Jerumenha (1.116); e Parnaguá (2.542) ${ }^{69}$. Vale esclarecer que, para o ano de 1798, não há informação sobre o número da população escrava e da livre no município de Marvão.

Apesar disso, durante a pesquisa foi possível observar que em anos posteriores a 1798, havia escravos no munícipio de Marvão, sendo possível afirmar que naquele ano o número de cativos no Piauí poderia ser superior a 13.250. Em 1830, viviam no Piauí 12.534 escravos, o que indica diminuição de 716 escravos em relação a 1798. Passados 35 anos desde 1830, esse número aumentou de 12.534 para 19.204, ou seja, 6.670 cativos a mais.

É importante ressaltar que, como qualquer documento, as tabelas postas nos relatórios dos presidentes da província piauiense são passíveis de erros. Isso é importante para percebemos que, mesmo tentando distanciar-se do objeto de estudo, a visão do historiador estará limitada e comprometida em virtude de sua subjetividade e das possíveis falhas contidas nas fontes que utiliza.

Não é possível reconstruir o passado, pois não é concebível chegar a uma verdade histórica objetiva e absoluta, justamente pela alteração que o meio provoca nas fontes e na escrita do historiador. Contudo, as fontes - documentos oficiais, jornais, entrevistas e todos os outros tipos de fontes que os historiadores utilizam para produzir/ construir seus textos -, apesar de sua carga subjetiva e das possíveis falhas, não podem ser menosprezadas, pois podem indicar, mesmo que parcialmente a "realidade" de terminada sociedade. Tendo isso em mente, não é possível negar que os dados sobre a população escrava contribuíram para uma compreensão, mesmo que parcial, do número de cativos que viviam no Piauí em diferentes anos.

Destacamos que não queremos reviver os fatos corridos, como pretendia o historiador Michelet aos estudar os acontecimentos da Revolução Francesa ${ }^{70}$, mas tentar compreender, ainda que parcialmente, os mecanismos de crescimento e diminuição do número de

69 Ibidem. Tabela 7.

70 Cf. MICHELET, Jules. História da Revolução Francesa. São Paulo: Companhia das Letras, 1989. 
escravos que viviam no Piauí. Os dados foram importantes para percebermos, mesmo que de modo relativo, o aumento e a diminuição dessa população. Tal flutuação é compreendida quando cruzamos as fontes e percebemos que o crescimento e o decrescimento podem ser justificados, em parte, pela entrada e saída de escravos no Piauí, através do tráfico transatlântico e provincial, por exemplo.

No relatório do presidente Manuel do Rego Barros Souza Leão, foi possível localizar outro censo da população do Piauí, datado de 21 de junho de 1871, segundo o qual havia na província 19.015 escravos.

Comparando os números de escravos existentes no Piauí no ano de 1865 com o número da população cativa existente em 1871, verificamos uma diminuição de 189 escravos. Porém, de acordo com o censo geral do Império, de 1872, existiam no Piauí, naquele ano, cerca de 23.795 escravos.

Após a análise desses dados, podemos fazer a seguinte observação: apesar de em alguns anos o número de escravos ter diminuído, se analisarmos o macro, chegaremos à conclusão de que a população cativa no Piauí, de 1762 até 1872 , em 110 anos, teve um aumento significativo. Saiu de 4.644 e chegou a 23.795 escravos, entre homens e mulheres. Isso representa um aumento de 19.151 pessoas na condição de escravas, no decorrer de mais de um século.

O surgimento e o crescimento da população escrava no Piauí ocorreram de duas formas distintas: endógeno e exógeno. O crescimento endógeno da população escrava corresponde ao nascimento de crianças dentro da província; já o exógeno é gerado quando há deslocamento de trabalhadores escravos de outras áreas para o Piauí.

Ao realizar estudos sobre a população escrava no Piauí, Marcondes e Falci conseguiram estimar um crescimento expressivo da taxa bruta de natalidade (TBN) dos escravos, "da ordem de 38,9 por mil para o munícipio de Jerumenha e de 36,7 para o munícipio de Teresina, no ano de $1856^{\prime 71}$.

71 MARCONDES, Renato Leite; FALCI, Miridan Britto Knox. Escravidão e reprodução no Piauí: Oeiras e Teresina (1875). Texto para discussão: Série Economia, Ribeirão Preto, v. 26, 2001. p. 6. 
Estas taxas mostram-se superiores às encontradas por Marcílio, no Rio de Janeiro, que atingira somente 27,5 por mil 1849. A reprodução endógena da população escrava parece ter durado até a década de 1870, pois em Oeiras, neste ano, a TBN encontrada atingiu 36,9 por mil. Embora tais evidências não devam ser generalizadas, elas já indicam que, ao menos topicamente, havia possibilidade de ocorrer crescimento vegetativo positivo da massa escrava. ${ }^{72}$

O crescimento endógeno da população cativa também foi observado pelo historiador Nunes. No quarto volume de Pesquisa para a história do Piauí, ele apresenta uma tabela de 1855 em que é possível notar que o crescimento natural da população escrava foi maior do que o crescimento natural da população livre naquele ano. Segundo dados da tabela, em 1855 o crescimento natural da população livre foi de 3,7 e o da população escrava foi de 4,4.

Para 1871, o pesquisador construiu outra tabela, na qual observamos que o crescimento natural dos escravos diminuiu em relação a 1855. Segundo o autor, em 1871 houve crescimento de apenas 3,6 para a população escrava e 4,2 para a população livre ${ }^{73}$.

Nas tabelas elaboradas por Nunes, também é possível observar que o número de óbitos da população livre era maior que os da população escrava ${ }^{74}$. Assim, o autor afirma: "era excelente a condição de escravo, sob todos os aspectos. No Piauí, havia maior natalidade e menor mortalidade de escravo"75. Para Nunes, isso se explica devido a seguinte causa: "é que não tínhamos agricultura, e o feitor, principal instrumento da selvageria, a que se referem os observadores, foi coisa rara no Piauí. Fazia-se o roçado apenas para a subsistência da senzala

72 MARCONDES, Renato Leite; FALCI, Miridan Britto Knox. Loc. Cit.

73 NUNES, Odilon. Pesquisa para a história do Piauí: Lutas partidárias e a situação da província.

Teresina: Fundapi, 2007. p. 250.

74 Ibidem, p. 250-251.

75 Ibidem, Loc. Cit. 
e do senhor e seus familiares, porque não havia mercado onde vender o excedente"76.

Do ponto de vista do teor das relações sociais entre senhor e escravo, a argumentação de Nunes pode ser válida para o início do processo de ocupação das terras que formariam o Piauí, momento no qual ocorreu o absenteísmo, quando os donos das fazendas não moravam e tampouco administravam suas terras e as fazendas, normalmente, eram geridas por um vaqueiro. Nesse período, em algumas fazendas piauienses "viviam um homem branco, com um escravo e em algumas se achava mais escravos e mais brancos, mas no comum se achava um homem branco só"77.

Após a fase absenteísta, vigilância, controle e violência nas relações entre senhor e escravos tornaram-se mais firmes, permitindo a Monsenhor Chaves ${ }^{78}$ afirmar que o período colonial e parte do imperial caracterizaram-se por submeter a vida dos escravos a um regime de ferro e fogo, com os castigos mais violentos e mais frequentes ${ }^{79}$.

No sistema escravista que ocorreu no Piauí, a condição dos escravos não era excelente. Nunes, ao afirmar o contrário, não levou em conta as constantes notícias de jornais sobre escravos severamente violentados por seus senhores ou por terceiros:

76 Ibidem, p. 251.

77 CARVALHO, ano apud MOTT, Luiz. Op. Cit., p. 98.

78 É importante destacar que Odilon Nunes e Joaquim Ferreira Chaves (Monsenhor) não são historiadores de formação, tampouco escreveram seus trabalhos pautados no rigor acadêmico. Para nós, os referidos pesquisadores são memorialistas; eles se entregam demasiadamente a reminiscências e experiências passadas com base na empiria, mas sem fazer críticas pertinentemente sobre as fontes. Seus trabalhos são pioneiros sobre o estudo da escravidão no Piauí; na década de cinquenta do século XX ambos tinham trabalhos publicados.

79 CHAVES, Joaquim Ferreira (Monsenhor). Obra completa. Prefácio de Teresinha Queiroz. Teresina: Fundação Cultural Monsenhor Chaves, 1998, p. 190. 
Escândalo - é intolerável o de que fomos testemunhas nesta capital, no domingo, 17 do corrente agosto de 1873, de 4 para 5 horas da tarde, na Praça da Constituição. Há esta hora, quando se achavam às janelas de suas casas diversas famílias, era conduzida por Policiais, quase arrastada para a cadeia, uma preta seminua, cujos gritos excitaram a indignação de todos contra o autor de tamanha violência. Admira que dentro de uma capital, à face das autoridades superiores, sem respeito ao pudor das famílias, se dê um fato desta ordem e que seja dele autor o próprio Comandante da Companhia de Polícia, segundo fomos informados, quando, antes de tudo, lhe cumpre velar para que se não afronte tão às escâncaras a moralidade pública e não se trate como a um irracional uma criatura humana, já por sua condição servil tão infeliz. Consta-nos que a preta, que se achava alugada ao Sr. Capitão J. Serafim, fora mandada arrastar pelo mesmo, completamente nua, e teria sido levada neste estado para a cadeia se uma alma caridosa não se tivesse compadecido dela, dando-lhe um pano com que conseguiu cobrir parte do corpo. ${ }^{80}$

A citação destacada foi localizada por Chaves durante pesquisa nos jornais do século XIX, mais precisamente no jornal A Imprensa, de 23 de agosto de 1873. A partir da análise dessa citação, podemos observar pessoas que agiam de forma violenta sobre os escravos, como foi o caso do comandante da polícia da província do Piauí, e aquelas que condenavam a violência de modo veemente, compadecendo-se das péssimas condições de vida às quais os escravos eram submetidos. Convém, no entanto, observar que a indignação estampada no jornal, possivelmente, também fosse motivada pelo fato da escrava estar seminua durante o ato de violência praticado nas ruas da capital da província do Piauí, o que poderia ser uma afronta ao pudor das famílias que presenciavam o fato. São fartas as notícias nos jornais do século XIX sobre violência praticada contra os escravos que viviam no Piauí:

80 Ibidem, p. 194. 
Barbaridade - Há cinco ou seis dias, cremos que na noite de 9, o sargento de polícia Marcelino Castelo Branco, rondando a cidade, encontrara um indivíduo que trazia ao pescoço uma coleira de ferro, visível por causa de uma ponta que se elevara de um lado, e mandara-o recolher a prisão. No dia seguinte, levado o preso a polícia, pelas indagações procedidas e pela confissão que fizera, soube-se que era escravo do senhor coronel comandante superior das Vilas das Barras, Manoel Rodrigues Lages; que dali da casa de seu senhor, fugira com designo de vir a esta cidade queixa-se as autoridades dos bárbaros castigos que recebia. E de feito, o pobre e miserável escravos estava de causar dó! Tinha as costas e as nádegas horrivelmente rasgadas pela ação do chicote! E estas, além disso, profundamente golpeadas por navalha ou faca bem amolada! A polícia satisfez-se sem horrorizar-se o deplorável estado dessa criatura, e a providência que tomou foi enviá-lo em paz ao seu desumano senhor. ${ }^{81}$

Duas observações são pertinentes a respeito dessa citação: 1) em alguns casos o Estado, na citação representado pela polícia, permitia a ação violenta praticada pelos senhores sobre os escravos; 2) apesar de o escravo ter sofrido várias mutilações, encontrou força para denunciar os maus-tratos praticados pelo seu senhor contra ele.

Feitas as observações, destacamos que o crescimento endógeno da população escrava pode ser percebido também nos relatórios dos presidentes da província. Por exemplo, ao analisamos o mapa dos casamentos, batizados e óbitos do ano de 1846, anexado ao relatório do presidente da província do Piauí, Zacarias de Góes e Vasconcelos, observamos que foram batizadas 693 crianças na condição de escravas, sendo 363 do sexo masculino e 330 do sexo feminino ${ }^{82}$.

Com o passar dos anos, o número de batizados de escravos aumentou, mas só até o começo da década de 1870. Afirmação que se torna compreensível por meio da análise do mapa com os dados dos

81 BARBARIDADE! A Época, Teresina, ano 3, n. 126, p. 3, 18 set. 1880.

82 VASCONCELOS, Zacarias de Goes e. Relatório do presidente da província do Piauí. [S.l.: s.n.], 1847. Mapa 12. 
casamentos, batizados e óbitos de 1855 presente no relatório do presidente da província do Piauí, Frederico D’Almeida e Albuquerque, segundo o qual houve 877 batizados de escravos, sendo 446 de homens e 431 de mulheres ${ }^{83}$. Já em 1870, o número de batizados sofreu uma diminuição sendo batizadas apenas 405 crianças na condição de escravas, 193 do sexo masculino e 212 do sexo feminino ${ }^{84}$. Esses dados ratificam a afirmação de Marcondes e Falci: "a reprodução endógena da população escrava parece ter durado até a década de 1870, pois percebemos que nesta década o número de batizados foi menor do que em anos anteriores" 85 .

O segundo fator que contribuiu para o crescimento da população escrava no Piauí entre 1762 e 1872 foram o tráfico transatlântico e o tráfico provincial. A princípio, ainda no século XVII, durante o processo de ocupação das terras que formariam o Piauí, os primeiros trabalhadores escravos foram trazidos para pelos egressos da Casa da Torre, na Bahia. Com o desenvolvimento das atividades laborais, a entrada de escravos ocorreu de formas diversas, como o tráfico negreiro direto da África. Um ponto de entrada de africanos escravizados era o porto de Parnaíba.

Próxima ao oceano Atlântico, Parnaíba também se comportava como um centro comercial de escravos. Para Falci, Parnaíba era o terceiro centro comercial de escravos do Piauí ${ }^{86}$. A historiadora aponta que no delta do rio Parnaíba havia mais de 300 ilhas, o que encorajava o contrabando de mercadorias e o comércio ilícito de escravos ${ }^{87}$.

Para o historiador português Paula, "era pelo porto da cidade de Parnaíba que se introduzia a maior parte de escravos clandestinos,

83 ALBUQUERQUE, Frederico D’Almeida e. Relatório do presidente da província do Piauí. [S.l.: s.n.], 1856. Mapa 9.

84 SOUZA LEÃO, Manuel do Rego Barros. Relatório do presidente da província do Piauí. [S.l.: s.n.], 1871. Anexo E.

85 MARCONDES, Renato Leite; FALCI, Miridan Britto Knox. Op. Cit., p. 6.

86 FALCI, Miridan Britto Knox. Escravos do sertão: demografia, trabalho e relações sociais. Teresina:

Fundação Cultural Monsenhor Chaves, 1995. p. 38.

87 Ibidem, Loc. Cit. 
destinados às capitanias mais ao Sul: Bahia, Pernambuco e até ao Rio de Janeiro" ${ }^{\text {. }}$. Dessa maneira, é possível que parte dos escravos que entravam no Piauí com destino as outras províncias do Brasil ficasse pelas terras piauienses.

Numa época em que as estradas terrestres eram precárias, a via marítima apresentava-se como um meio importante de integração entre as diferentes regiões do Brasil. Em Parnaíba, devido a sua localização geográfica próxima ao oceano e por estar à beira de rio Igaraçu, o tráfico de mercadorias foi observado, como indica a nota do jornal O Conciliador Piauhyense:

Na Parnaíba, a única cidade beira-mar que temos, não sente só a necessidade da mudança dos empregados de polícia, como em outro número reclamamos; necessita-se de uma enérgica, e efetiva inspeção nos negócios que dizem respeito à alfandega, a fim de desanimar os contrabandistas, e aumentar as rendas. [...] Neste gênero se faz naquela cidade, e há longos anos um contrabando imenso, que a impunidade tem feito acreditar na população ter o mesmo efeito que o comércio lícito. ${ }^{89}$

O contrabando de mercadorias existia em Parnaíba e, como o trabalhador escravizado era certamente uma mercadoria valorizada entre tantas contrabandeadas, cremos que foi forte o contrabando de escravos no porto de Parnaíba.

Para Falci, o comércio inter-regional de escravos em Parnaíba foi percebido pelo governo português, que, “em Carta Régia ao Conde de Rezende, aconselha a criação de um entreposto de escravos em Par-

88 PAULA, Antônio Neto de. A carreira marítima Parnaíba-Lisboa: finais do século XVIII: 1779-1793.

Teresina. EDUFPI, 2000. p. 25.

89 QUANTO mais forte e leal se mostrar o gabinete. O Conciliador Piauhyense, Teresina, ano1, n. 15, p. 1, 24 ago. 1857. 
naíba, no final do século XVIII"9o. A historiadora, contudo, não sabe ao certo quantos foram para outras províncias ou quantos ficaram no Piauí, porém destaca que "as práticas de contrabando assumiram grandes proporções, principalmente no final do século XVIII e início do século XIX"91.

Segundo a autora, em 1808 "as exportações pelo porto de Parnaíba totalizaram 106: 420\$000 [réis], e as importações, 58:504\$900 [réis]. Ainda que de pequeno movimento, observa-se o superávit na balança comercial e vê-se que cerca de $60 \%$ dos gastos com a importação foram relativos à importação de escravos do continente" ${ }^{2}$, ou seja, com a importação de escravos vindos de outras províncias do Brasil, que também entravam pelo porto de Paranaíba. Ainda segundo as argumentações da historiadora, o valor em dinheiro relativo à importação de escravos que entraram em 1808 pelo porto de Parnaíba chegou a 36:400\$000 réis ${ }^{93}$.

Esses dados reforçam nossa convicção de que a movimentação comercial lícita e ilícita de escravos era forte no porto de Parnaíba, que, para Falci, servia também como um ponto de escala, já que Parnaíba estava situada entre dois grandes polos comerciais da época - São Luís e Recife -, o que poderia favorecer o contrabando de diversas mercadorias, inclusive escravos.

Além da entrada de cativos vindos diretamente da África para o Piauí, havia também os que trazidos de outras províncias. Essa afirmação ficou mais patente após analisarmos as listas de classificação de escravos, em que, por exemplo, na relação dos escravos pertencentes a Virgulino Maria de Jesus, residente no município de Parnaíba,

\footnotetext{
90 FALCI, Miridan Britto Knox. Op. Cit., p. 38.

91 Ibidem, Loc. Cit.

92 Ibidem, p. 39.

93 Ibidem, Loc. Cit.
} 
em 1857, constavam apenas oito escravos, sendo três naturais do Maranhão ${ }^{94}$.

Na relação dos escravos pertencentes a Joaquim de Sousa Vasconcelos, do município de Campo Maior, dois de seus seis escravos eram da província do Ceará: João, 30 anos de idade, cor parda, solteiro, com valor de 800 mil réis; José, 22 anos de idade, cor preta, solteiro, com valor de 900 réis ${ }^{95}$.

Na relação dos escravos pertencentes a José Maria Ferreira, do município de União, cinco de dez escravos eram de outras províncias. São eles: Margarida, 25 anos de idade, cor parda, solteira, natural da província do Maranhão, com valor de 700 mil réis; Joaquina, 35 anos de idade, cor mulata, solteira, natural da província do Maranhão, com valor de 600 mil réis; José, 40 anos de idade, cor preta, solteiro, natural da província do Maranhão, com valor de 900 mil réis; Lucia, 26 anos de idade, cor cabra, solteira, natural da província do Maranhão, com valor de 800 mil réis; Catarina, 24 anos de idade, cor cabra, solteira, natural da província do Ceará, com valor de $850 \mathrm{mil}$ réis ${ }^{96}$.

Tendo conhecimento do crescimento da população escrava e tendo verificado o processo de recuo econômico da principal economia do Piauí - a pecuária-, destacamos que a existência de trabalhadores escravos não estava diretamente ligada ao crescimento econômico, isto é, ela independia dele.

Ao afirmar isso, levamos em consideração a necessidade de trabalhadores para realizar os serviços demandados pela atividade pastoril e agrícola, independentemente de seu caráter natural de crescimento econômico, havendo espaço para a mão de obra escrava e

94 RELAÇÃO da classificação de escravos do município de Parnaíba. Assunto: Coletoria. Caixa: 338. Século XIX: anos, 1835 e 1886.

95 RELAÇÃO da classificação de escravos do município de Campo Maior. Assunto: coletoria. Caixa: 798. Século XIX: anos 1800 e 1889.

96 RELAÇÃO da classificação de escravos do município de União. Assunto: coletoria. Caixa: sem número. Século XIX: anos 1820 e 1850. 
para a livre. Assim, a existência de escravos no Piauí estava ligada principalmente ao trabalho ou à necessidade de realizar serviços em diferentes setores.

Todavia, destaca-se que a agricultura estava necessitando de mão de obra, pois, no início do século XIX, saiu de sua condição de pequena agricultura para atividade de produção mercantil, abastecendo o mercado interno do Piauí e exportando para fora das terras piauienses e do Brasil, como ocorreu, por exemplo, com o algodão exportado para a Grã-Bretanha.

No Piauí, a presença de escravos de etnia africana e de seus descendentes é inquestionável, porém, ao que parece, essa população não ultrapassou o número de 24 mil indivíduos. Isso faz sentido devido ao próprio sistema econômico da região. A pecuária, principal atividade econômica, era desenvolvida em sistema extensivo, o que demandava pouca mão de obra, e a agricultura, apesar de seu crescimento no século XIX, não chegou aos mesmos níveis de produção praticados na zona açucareira, por exemplo.

Mota e Barroso Junior indicam que no Maranhão, em 1798, havia 36.877 escravos, entre homens e mulheres ${ }^{97}$. No Ceará, em 1872, havia 31.603 escravos $^{98}$, entre homens e mulheres. Em ambas as localidades, ao que tudo indica, o número de escravos sempre foi maior que no Piauí, mas, mesmo em pouco número, eles estiveram presentes no Piauí, trabalhando tanto na pecuária como na agricultura.

97 MOTA, Antônia da Silva; BARROSO JUNIOR, Reinaldo dos Santos. O norte da América Portuguesa e o escravo africano: tráfico de escravos e população negra na capitania do Maranhão (1750-1810). Cidade: Editora, ano provável. No prelo.

98 BRASIL. Recenseamento do Brazil em 1872. Rio de Janeiro: Typ. G. Leuzinger, [1874?]. 


\section{0 braço forte dos trabalhadores escravos no Piauí}

A questão da mão de obra nas fazendas de gado do sertão nordestino até o presente só tem sido alvo de interpretações falsas, fantasiosas, senão rocambolescas. Todos os nossos mais ilustres historiadores econômicos - de Roberto Simonsen, Caio Prado Júnior, a Werneck Sodré e Celso Furtado - repetiram o mesmo erro de Capistrano de Abreu: sem nenhuma evidencia empírica, divulgaram que no sertão pecuarista predominou o trabalho livre do índio, posto que o escravo negro, montado a cavalo, inevitavelmente fugiria, donde a incompatibilidade existente entre a pecuária e a escravidão. ${ }^{99}$

A inquietação de Mott é em relação à tese que defendia a incompatibilidade da mão de obra escrava com a atividade pecuarista, que durou por muito tempo na historiografia nacional e piauiense. Nunes chegou a dizer que "no Piauí o trabalho servil não era uma condição da economia"100, afirmação cuja base é a concepção de que a principal economia do Piauí - a pecuária - baseava-se nas condições naturais.

Mott deu argumentos contrários às ideias que apontavam para uma incompatibilidade entre a economia pecuarista e a mão de obra escrava. Segundo ele, coexistiram a mão de obra livre e a indígena ao mesmo tempo que o trabalho escravo era bastante utilizado na labuta com o gado. Dessa forma, o antropólogo não se omitiu ao defender que "o escravo negro sempre foi uma presença importante e indispensável nas fazendas de criatório, superior ao braço indígena, quiçá mesmo ao braço livre" ${ }^{\prime \prime}$.

Ao mesmo tempo que afirmou que o escravo estava presente na economia pastoril, o antropólogo apontou para uma convivência de variados indivíduos na pecuária, o que também foi percebido por

99 MOTT, Luiz. Op. Cit., p. 125.

100 NUNES, Odilon. Pesquisa para a história do Piauí ... Op. Cit., p. 252.

101 MOTT, Luiz. Op. Cit., p. 107. 
Scott ao analisar o trabalho escravo nas lavouras de cana-de-açúcar em Cuba. Segundo a autora, "os proprietários cubanos utilizavam escravos, trabalhadores chineses e iucategos contratados, condenados, escravos alugados, diaristas livres, assalariados, trabalhadores remunerados por tarefa e parceiros"102.

Para Scott, “a coexistência dessas formas de trabalho, às vezes numa mesma fazenda, fornece um exemplo notável de flexibilidade no interior de uma economia que ainda se baseava fundamentalmente no trabalho escravo"103. Foi essa flexibilidade que possibilitou a coexistência de trabalho escravo e livre na economia pastoril com as características da pecuária desenvolvida no Piauí, permitindo inclusive a utilização de escravas no trabalho com o gado, como nos indica Lima:

As mãos das mulheres não se limitavam ao manejo dos machados, facões, foices e enxadas apenas para produzir alimentos ou produtos que resultavam em vícios. Manejavam, com a mesma destreza, as mesmas velhas ferramentas para garantir bons pastos para a criação do gado. Ao lado dos homens e com a força dos braços, abriam caminho entre as matas e caatingas para que o gado se deslocasse pelos caminhos, chegasse a reservas naturais de água e fosse conduzido com segurança às fazendas e currais. ${ }^{104}$

Mott não aprofundou a análise sobre o trabalho desenvolvido pelas escravas nem o estudo sobre a mão de obra escrava no perímetro urbano, mas destacou que em uma economia tão rústica as categorias escravo doméstico e escravos de ganho, sendo essa distinção a principal característica do sistema escravista que prevaleceu na zona urbana, foram coisa rara no Piauí105.

102 SCOTT, Rebeca J. Emancipação escrava em Cuba: a transição para o trabalho livre, 1860-1899. Rio de Janeiro: Paz e Terra; Campinas: Editora da Unicamp, 1991. p. 19.

103 Ibidem, Loc. Cit.

104 LIMA, Solimar Oliveira. Braço forte: trabalho escravo nas Fazendas da Nação no Piauí (1822-1871).

Passo Fundo: UPF Editora, 2005. p. 80.

105 MOTT, Luiz. Op. Cit., p. 111. 
Na pecuária, os trabalhadores escravos construíam currais e peavam o gado, e muitos fazendeiros "contavam com seus escravos, agregados e vaqueiros para as funções de guias e passadores"106, atividades desenvolvidas ao levar o gado para as feiras ou ao conduzi-los aos matadouros. Contudo, os trabalhadores escravos também trabalhavam nas plantações.

Até o início do século XX, a produção agrícola brasileira dependia basicamente das determinações naturais, visto que eram incipientes as inovações químicas, genéticas e tecnológicas que viriam a alterar o ciclo de cultivo e/ou a demanda por trabalho. Nessa perspectiva, era extrema a dependência da demanda por mão de obra na agricultura, com momentos de mais trabalho, que, assim, necessitavam de mais trabalhadores. Nessas condições, a mão de obra escrava foi utilizada em vários setores e lugares do Brasil.

Luna e Klein, ao analisar a economia e a sociedade escravista em Minas Gerais e em São Paulo na primeira metade do século XIX, observaram que os centros exportadores do Vale do Paraíba e oeste paulista possuíam um número médio de escravos desenvolvendo diversas atividades. Além disso, perceberam que:

Os maiores plantéis estavam nos engenhos de açúcar, presentes tanto em São Paulo como em Minas Gerais. Os engenhos paulistas possuíam em média 31 escravos - havia 585 engenhos, com um total de 18.224 cativos - um quarto da força de trabalho escravo total da província. Em Minas Gerais os 282 engenhos eram menores - possuindo apenas vinte cativos por unidade - e controlavam apenas $5 \%$ dos escravos da província. Em São Paulo, o café concentrava-se no Vale do Paraíba, que continha 1.725 fazendas de café, das quais menos da metade possuía escravos. ${ }^{107}$

106 BRANDÃO, Tanya Maria Pires. O escravo na formação social do Piauí... Op. Cit., p. 68.

107 LUNA, Francisco Vidal; KLEIN, Herbert S. Economia e sociedade escravista: Minas Gerais e

São Paulo em 1830. In: LUNA, Francisco Vidal; COSTA, Iraci Del Nero da; KLEIN, Herbert S. 
As argumentações de Luna e Klein nos direcionam para a compreensão de que nas grandes fazendas, com cultivos voltados principalmente para o mercado externo, se encontrava um maior plantel de escravos. Porém, eles também afirmam que "não havia atividade econômica onde o trabalho escravo não estivesse presente. Mesmo nas atividades econômicas mais pobres, como a agricultura de gêneros alimentícios e o artesanato, era comum a presença de escravos"108.

No Piauí, a presença de escravos e escravas na agricultura foi notada por alguns pesquisadores, com a historiadora Falci. Em Escravos do Sertão: demografia, trabalho e relações sociais, ela apontou que a participação da mão de obra dos trabalhadores escravos na economia piauiense não estava apenas restrita à economia pastoril. Segundo a autora, os escravos foram trazidos às terras piauienses "para desenvolver não só a criação do gado e a produção da carne charqueada com o sal, abundante no litoral, mas também para implantar o cultivo do algodão nas regiões mais úmidas e desenvolver o cultivo do fumo"109.

Nos roçados, escravos e escravas desenvolviam várias atividades, como a limpeza do solo para fazer o plantio. O preparo da terra "iniciava-se com a 'broca' - o corte de pequenas árvores com foices -; em seguida, fazia-se a 'derrubada' - o corte das árvores maiores com machados - e, por fim, ateava-se fogo. Após a 'queima, esperavam-se as primeiras chuvas para o início do plantio"110, que quase sempre ocorria nos primeiros meses do ano, em virtude da estação chuvosa no Piauí ocorrer nesse período.

Lima aponta que nas fazendas era predominante o trabalho de escravas nos roçados. Segundo ele, em 1854 foi verificado, a partir de um arrolamento sobre a população por sexo e ocupação, fornecido

(Org.). Escravismo em São Paulo e Minas Gerais. São Paulo: Edusp: Imprensa Oficial do Estado de

São Paulo, 2009. p. 223.

108 Ibidem, Loc. Cit.

109 FALCI, Miridan Britto Knox. Op. Cit., p. 36.

110 LIMA, Solimar Oliveira. Braço forte... Op. Cit., p. 74. 
pelos inspetores às autoridades, na inspeção Piauí, que o trabalho na lavoura era quase que exclusivamente feminino. "Apenas três fazendas apontaram possuir roceiros, duas tinham apenas um trabalhador nos plantios. A outra, onde residia o inspetor, arrolou nove trabalhadores, enquanto possuía 12 roceiras, incluindo uma de 10 e duas de 11 anos"111. Para o autor, na agricultura praticada nas fazendas, a mandioca era o plantio de maior importância "por potencializar a existência de uma rede de integração socioeconômica em decorrência do processo de fabricação da farinha"112.

Rodrigues apontou que um dos primeiros estudiosos que mencionou o saber indígena e as propriedades alimentícias da mandioca foi o francês Jean de Léry, "que fez uma descrição alongada sobre o preparo desse alimento em 1556. Ele disse haver duas espécies de raízes, aypi e maniot, que levavam de 3 a 4 meses entre a plantação e a colheita"113. Porém Rodrigues, a partir das considerações feitas por Gabriel Soares de Sousa, indicou também que havia variedades de mandioca que poderiam levar um tempo maior para estarem prontas para a colheita. Segundo o historiador, "a manipocamirim e a, manaibuçu estavam prontas para consumo um ano depois do plantio e sobreviviam de 3 a 4 anos sob a terra, enquanto a manaitinga e a parati podiam ser colhidas 8 meses após o plantio e se estragavam depois de um ano, requerendo solos arenosos para vicejar"114.

Rodrigues é enfático ao afirmar que "todas as variedades deviam ser plantadas em tempo seco, já que as chuvas faziam apodrecer as raízes, e todas tinham na formiga seu maior inimigo natural"15. Dessa forma, não faltava trabalho para os escravos nas lavouras, visto que no período das chuvas poderiam trabalhar no plantio de leguminosas

\footnotetext{
111 LIMA, Solimar Oliveira. Braço Forte... Loc. Cit.

112 Ibidem, Loc. Cit.

113 RODRIGUES, Jaime. “De farinha, bendito seja Deus, estamos por agora muito bem”: uma história da mandioca em perspectiva atlântica. Revista Brasileira de História, São Paulo, v. 37, n. 74, p. 6, 2017. 114 Ibidem, p. 7.

115 Ibidem, Loc. Cit.
} 
cultivadas nas estações chuvosas e no período de estiagem poderiam trabalhar, entre outros afazeres, no plantio da mandioca.

Porém, destaca-se que, no Piauí, o plantio da mandioca poderia ocorrer também em consonância com o de outras culturas, como feijão e milho, adaptáveis ao período chuvoso. Mas "o que predominou foi um tipo de plantação específica chamada 'roçado de mandioca"'116.

O plantio da mandioca é realizado a partir de manivas, pedaços de caule de plantas adultas e saudáveis em trono de 15 centímetros de comprimento. As manivas são colocadas em sulcos, rego aberto na terra, com cerca de 5 a 10 centímetros de profundidade, podendo ser dispostas na posição horizontal ou vertical. Passado o trabalho com o plantio, os roçados de mandioca não requeriam grandes cuidados, pois a ela poderia se desenvolver sem nenhuma interferência dos trabalhados. Segundo Lima, "o plantio da mandioca seguia o método ainda hoje utilizado por pequenos proprietários do Nordeste"117.

A colheita da mandioca se resumia basicamente ao arranque ou desenraizamento da planta adulta com as mãos. Após o arranque da planta, separava-se a raiz, conhecida como "mandioca", com um corte de facão ou cutelo.

A mandioca poderia servir de alimento para o gado ou ser utilizada para fazer farinha. Rodrigues afirma que a preparação da farinha de mandioca poderia ser feita de modos diversos, indicando que "de acordo com Jean de Léry, havia uma mais cozida, dura e resistente ao tempo"118.

Após a colheita, parte da produção de mandioca era então levada para a casa de farinha, composta por um sistema de ralação, prensa e forno. No Piauí, existiam algumas casas de farinha ou casas de forno. Lima indica que,

116 LIMA, Solimar Oliveira. Braço forte... Op. Cit., p. 74-75.

117 Ibidem, p. 75.

118 RODRIGUES, Jaime. Op. Cit., p. 8. 
A casa de forno da fazenda São Tomé, uma grande propriedade particular, pertencente ao juiz ordinário Dionísio Gonçalves Vilarinho, nas cercanias de Oeiras, por exemplo, não passava de uma construção tosca, sem paredes, "coberta de palha e sustentada por madeiras nos quatro cantos". Debaixo da latada era assentado o forno, uma espécie de bacia, rasa e grande, feita "de cobre e medindo 17 palmos em roda", colocada sobre uma base de barro com uma "entrada central para as lenhas [madeira]". No lado oposto, para evitar os "calores do forno", ficava a "máquina de triturar a mandioca", ou o caititu [cilindro de madeira ao longo do qual se adaptam serrilhas metálicas, com uma das extremidades conformada em roldana de gorne para a passagem da correia ou corda que imprime a rotação] disposto sobre uma "banqueta" ou mesa, impulsionado pelas mãos dos trabalhadores. ${ }^{119}$

A descrição, feita por Lima, da casa de forno da fazenda São Tomé indica que o local de transformação da mandioca em farinha era rústico, o que tornava as condições de trabalho ainda mais precárias. Porém, o autor aponta que, "apesar de rústica, a casa não era um investimento barato, por isso era inacessível às pequenas fazendas, onde a produção de mandioca, e consequentemente a de farinha, era reduzida"120.

Na produção da farinha de mandioca, era comum a utilização de mulheres e homens, escravos e livres. "Na fazenda Poções, os homens escravos e 'dois pretos livres', moradores na fazenda, 'agregados', eram forneiros [responsáveis pelo trabalho diretamente no forno, como controlar a temperatura]"121. Segundo o autor, as escravas desenvolviam a atividade de descascar as raízes da mandioca.

119 LIMA, Solimar Oliveira. Braço forte... Op. Cit., 2005, p. 75.

120 Ibidem, p. 76.

121 LIMA, Solimar Oliveira. Braço forte... Op. Cit., p. 76. 
Dispostas em rodas e com facas afiadas, passavam o dia inteiro sentadas trabalhando, conversando e cantando. Ralar mandioca era uma atividade exclusivamente feminina e exigia grande concentração. Sentada ao lado da banqueta do caititu, uma mulher comprimia com as mãos a mandioca descascada sobre o equipamento, sendo comuns acidentes, que resultavam, quase sempre, em perdas de dedos. Havia ainda a presença de um encarregado da casa de forno, quase sempre o criador da fazenda, que realizava a farinha. Este homem controlava os alqueires de farinha fabricada e os trabalhadores. ${ }^{122}$

A partir dessa citação percebemos que a casa de forno, apesar de ser um local rústico que possibilitava condições inóspitas de trabalho aos trabalhadores, permitia, ao mesmo tempo, condições favoráveis a sua sociabilidade. Lima destaca que "a farinhada era uma atividade esperada, festejada. A produção de farinha simbolizava 'tempos de farturas' e prosperidade"123, porém, essa prosperidade não era para os escravos, e sim para os produtores, negociantes e vendedores; assim, era de se esperar que esses também festejassem a chegada das farinhadas.

Para os escravos, as farinhadas eram tempos de mais trabalho, mas também eram momento de aumentar a rede de comunicação e sociabilidade. Assim, "trabalhadores de diferentes propriedades formavam uma comunidade ao redor da casa de forno, construíam cabanas 'sem paredes' onde dormiam, cozinhavam e, à noite, após o trabalho, faziam batucadas"124.

As batucadas eram atos de comemoração dos escravos. Acreditamos que eram também atos de resistência às condições precárias de trabalho que lhes eram impostas, pois nelas os escravos tinham a oportunidade de organizar planos para fugir ou até mesmo matar

122 Ibidem, Loc. Cit.

123 Ibidem, p. 77.

124 Ibidem, Loc. Cit. 
seus senhores. Além disso, serviriam como meio para aliviar o dia pesado de trabalho.

\section{Considerações finais}

Nossos desafios com este trabalho são nítidos. O primeiro foi tornar o leitor ciente de que o Piauí se comportou como principal fornecedor de gado vacum e seus derivados para diferentes localidades do Brasil até por volta do final do século XVIII, momento em que, devido principalmente às conjunturas externas às plagas piauienses, houve a retração na economia pecuarista, embora não o suficiente para ocasionar seu fim, contribuindo para que alguns fazendeiros diversificassem sua produção. Isso foi fundamental para possibilitar que a agricultura saísse de sua condição de subsistência e assumisse posição de produção mercantil.

O segundo foi demonstrar que a necessidade do trabalhador escravo no Piauí estava intimamente ligada a um sistema produtivo assentado na exploração do seu trabalho. Contudo, não tivemos a pretensão de afirmar que a escravidão tinha sido a única forma de trabalho vigente nos períodos colonial e imperial, pois sabemos que foi utilizada inclusive a mão de obra de pessoas livres. Mas destaca-se que por muito tempo houve predominância da utilização da mão de obra escrava, com o início de um processo de transição da mão de obra cativa para a livre na década de setenta do século XIX, como nos indicou a documentação.

Temos consciência de que a escravidão tinha legitimidade também por ser uma demarcadora das diferenças de classe, reguladora e definidora das hierarquias sociais dentro de uma sociedade mestiça e patriarcal. Assim, pode ser crível que dentro dessa sociedade possuir escravo poderia significar um elemento de distinção entre os indivíduos.

É de se ressaltar que a escravidão tem relação com as questões de demarcação social, mas não tanto ou apenas com ela, pois acre- 
ditamos e defendemos que os escravos serviam mais como força de trabalho do que como objetos de ostentação social.

\section{Referências bibliográficas}

ALBUQUERQUE, Frederico D’Almeida e. Relatorio do presidente da provincia do Piaui. [S.l.: s.n.], 1856.

ABREU, Capistrano de. Capitulos de historia colonial: 1500-1800. Brasilia, DF: Conselho Editorial do Senado Federal, 1998.

A EPOCA. Teresina: [s.n.], ano 1, n. 37, 13 dez. 1878.

ALGRANTI, Leila M. O feitor ausente: estudos sobre a escravidao urbana no Rio de Janeiro (1808-1822). Petropolis: Vozes, 1988.

ASSUNCAO, Manuel Antunes de. Relacao dos escravos das fazendas da Inspecao de Nossa Senhora de Nazare, de todos quantos nelas se acham tambem os da Residência com as suas idades pouco mais ou menos. [S.l: s.n], 1778. Manuscrito. Disponivel em: <https://bit.ly/2TG6F4c > . Acesso em: 3 mar. 2010.

BARBARIDADE! A Epoca, Teresina, ano 3, n. 126, p. 3, 18 set. 1880.

BRANDAO, Tanya Maria Pires. O escravo na formacao social do Piaui: perspectiva historica do seculo XVIII. Teresina: EDUFPI, 1999.

BRANDAO, Tanya Maria Pires. A elite colonial piauiense: familia e poder. 300 f. Tese (Doutorado em Historia Social) - Faculdade de Filosofia, Letras e Ciências Humanas, Universidade de Sao Paulo, Sao Paulo, 1993.

BUAINAIN, Antonio Marcio; GARCIA, Junior Ruiz; VIEIRA FILHO, Jose Eustaquio Ribeiro. Dinamica da economia e da agropecuaria no Matopiba. Rio de Janeiro: Ipea, 2017.

CARVALHO, Antonio Francisco Pereira de. Relatorio do presidente da provincia do Piaui. [S.l.: s.n.], 1854.

CARVALHO, Genimar Machado Resende de. Construtores e aprendizes: cativos da nacao e educandos artifices nas obras publicas da construcao de Teresina (1850-1873). Porto Alegre: FCM Editora, 2013.

CARVALHO, Miguel de. Descricao do sertao do Piaui. 2. ed. Teresina: Academia Piauiense de Letras, 2009.

BRASIL. Recenseamento do Brazil em 1872. Rio de Janeiro: Typ. G. Leuzinger, [1874?]. 
COSTA FILHO, Alcebiades. A escola do sertao: ensino e sociedade no Piaui, 1850-1889. Teresina: Fundacao Cultural Monsenhor Chaves, 2006.

CHAVES, Joaquim Ferreira (Monsenhor). Obra completa. Prefacio de Teresinha Queiroz. Teresina: Fundacao Cultural Monsenhor Chaves, 1998.

ARQUIVO HISTORICO ULTRAMARINO.AHU_ACL_016, cx 12, Doc. 721.

ARQUIVO HISTORICO ULTRAMARINO. AHU_ACL_CU_ 16, cx. 12, Doc. 730.

DORIA, Franklin Americo de Menezes. Relatorio do presidente da provincia do Piaui. [S.l.: s.n.], 1864.

FALCI, Miridan Britto Knox. Escravos do sertao: demografia, trabalho e relacoes sociais. Teresina: Fundacao Cultural Monsenhor Chaves, 1995.

FREITAS, Jose Manuel de. Relatorio do presidente da provincia do Piaui. [S.l.: S.n.], 1868.

FREIRE, Adelino Antonio de Luna. Relatorio do presidente da provincia do Piaui. [S.l.: s.n.], 1867.

FUNDACAO CENTRO DE PESQUISAS ECONOMICAS E SOCIAIS DO PIAUI. Conjuntura economica e social: boletim analitico anual, 2016. Teresina: Cepro, 2017. Disponivel em: $<$ https://bit.ly/3aniixu>. Acesso em: 4 mar. 2020.

GORENDER, Jacob. O escravismo colonial. 4. ed. Sao Paulo: Fundacao Perseu Abramo, 2010.

HENRIQUE, Juliana da Silva. Os "Livros de Registro de Entrada de Gado" da Feira de Capoame (1784-1811). In: CONFERÊNCIA INTERNACIONAL DE HISTORIA ECONOMICA, 4.; ENCONTRO DE POS-GRADUACAO EM HISTORIA ECONOMICA, 6., 2012, Sao Paulo. Anais... Sao Paulo: Universidade de Sao Paulo, 2012. p. 1-24.

INSTITUTO BRASILEIRO DE GEOGRAFIA E ESTATISTICA. Levantamento sistematico da producao agricola. Rio de Janeiro: IBGE, 2017. Disponivel em: <https://bit.ly/38lupA5>. Acesso em: 4 abr. 2020.

JUNQUEIRA, Joao J. D'Oliveira. Relatorio do presidente da provincia do Piaui. [S.l.: s.n.], 1858.

LIMA, Solimar Oliveira. Trabalho escravo nas charqueadas do Piaui: uma aproximacao. Informe Economico, Teresina, n. 15, p. 35-59, jun. 2003.

. Braco forte: trabalho escravo nas fazendas da nacao no Piaui (18221871). Passo Fundo: UPF Editora, 2005. 
Origens e espacos de producao das fazendas pastoris do Piaui. In: MAESTRI, Mario (Org.). Peoes, gauchos, vaqueiros, cativos campeiros: estudos sobre a economia pastoril no Brasil. Passo Fundo: UPF Editora, 2009. p. 349-375.

. Fazenda: pecuaria, agricultura e trabalho no Piaui escravista (sec. XVII-XIX). Teresina: EDUFPI, 2016.

LUNA, Francisco Vidal; KLEIN, Herbert S. Economia e sociedade escravista: Minas Gerais e Sao Paulo em 1830. In: LUNA, Francisco Vidal; COSTA, Iraci Del Nero da; KLEIN, Herbert S. (Org.). Escravismo em Sao Paulo e Minas Gerais. Sao Paulo: Edusp: Imprensa Oficial do Estado de Sao Paulo, 2009. p. 197-228.

MARCONDES, Renato Leite; FALCI, Miridan Britto Knox. Escravidao e reproducao no Piaui: Oeiras e Teresina (1875). Texto para discussao: Serie Economia, Ribeirao Preto, v. 26, 2001.

MAVIGNIER, Diderot dos Santos. No Piauhy: na terra dos Tremembes. Parnaiba: Sieart, 2005.

MICHELET, Jules. Historia da Revolucao Francesa. Sao Paulo: Companhia das Letras, 1989.

MOTA, Ignacio Francisco Silveira da. Relatorio do presidente da provincia do Piaui. [S.l.: s.n.], 1850.

MOTA, Antonia da Silva; BARROSO JUNIOR, Reinaldo dos Santos. O norte da America Portuguesa e o escravo africano: trafico de escravos e populacao negra na capitania do Maranhao (1750-1810). São Luiz, EDUFMA. No prelo.

MOTT, Luiz. Piaui colonial: populacao, economia e sociedade. 2. ed. Teresina: Academia Piauiense de Letras, 2010.

MORAES, Carlos Dante de. Figuras e ciclos da historia rio-grandense. Porto Alegre: Globo, 1959.

NUNES, Odilon. Estudos de historia do Piaui. 2. ed. Teresina: Academia Piauiense de Letras, 2014.

. Pesquisa para a historia do Piaui: lutas partidarias e a situacao da provincia. Teresina: Fundapi, 2007.

PIAUI. Fazendas Nacionais. Livro de registro dos oficios e mais ordens expedidas pelo Governo Temporario: vai rubricado por mim e depois de numerado, como presidente do mesmo governo. Oeiras: [s.n.], 25 de janeiro de 1823. Caixa: 147. 
PIAUI. Secretaria de Governo; Fundo- Palacio do Governo; Grupo - Parnaiba; Serie- Alfandega de Parnaiba; Ano- 1835-1928.

PIAUI. Secretaria de Governo do Piaui. Assunto: municipio - Valenca. Anos: 1875 a 1893.

PIAUI. Secretaria de Governo do Piaui. Assunto: municipio- Sao Raimundo Nonato. Ano: 1875.

PAULA, Antonio Neto de. A carreira maritima Parnaiba-Lisboa: finais do seculo XVIII: 1779-1793. Teresina. EDUFPI, 2000.

QUANTO mais forte e leal se mostrar o gabinete. O Conciliador Piauhyense, Teresina, ano 1, n. 15, p. 1, 24 ago. 1857.

RELACAO da classificacao de escravos do municipio de Parnaiba. Assunto: Coletoria. Caixa: 338. Seculo XIX: anos, 1835 e 1886.

RELACAO da classificacao de escravos do municipio de Campo Maior. Assunto: coletoria. Caixa: 798. Seculo XIX: anos 1800 e 1889.

RELACAO da classificacao de escravos do municipio de Uniao. Assunto: coletoria. Caixa: sem numero. Seculo XIX: anos 1820 e 1850.

RIBEIRO, Darcy. O povo brasileiro: a formacao e o sentido do Brasil. 2. ed. Sao Paulo: Companhia das Letras, 1995.

RODRIGUES, Jaime. "De farinha, bendito seja Deus, estamos por agora muito bem": uma historia da mandioca em perspectiva atlantica. Revista Brasileira de Historia, Sao Paulo, v. 37, n. 75, p. 69-95, 2017.

SCOTT, Rebeca J. Emancipacao escrava em Cuba: a transicao para o trabalho livre, 1860-1899. Rio de Janeiro: Paz e Terra; Campinas: Editora da Unicamp, 1991.

SILVA, Mairton Celestino da. Batuque na rua dos negros: escravidao e policia na cidade de Teresina, seculo XIX. Teresina: EDUFPI, 2014.

SILVA, Mairton Celestino da. Um caminho para o Estado do Brasil: colonos, missionarios, escravos e indios no tempo das conquistas do Estado do Maranhao e Piaui, 1600-1800. 2016. Tese (Doutorado em Historia), Centro de Filosofia e Ciências Humanas, Universidade Federal de Pernambuco. Recife, 2016.

SOUZA LEAO, Manuel do Rego Barros. Relatorio do presidente da provincia do Piaui. [S.l.: s.n.], 1871.

VASCONCELOS, Zacarias de Goes e. Relatorio do presidente da provincia do Piaui. [S.l.: s.n.], 1847.

Recebido em: 22/03/2018 - Aprovado em: 14/03/2019 